\title{
Kan førekomsten av nokre spesielle feiltypar predikere den samla førekomsten av rettskrivings- og bøyingsavvik i nynorsktekstar? Ein statistisk analyse
}

\author{
Terje Myklebust` og Jan Olav Fretland \\ Høgskulen på Vestlandet
}

\section{Samandrag}

I denne artikkelen studerer vi om ein tekstforfattars generelle tilbøyelegheit til å gjere rettskrivingsog bøyingsavvik i nynorsktekstar kan estimerast ut i frå kunnskapar om forfattarens tilbøyelegheit til å gjere nokre spesielle feiltypar. Analysen indikerer at førekomsten av spesielt to feiltypar er gode indikatorar for den totale feilmengda i vårt tekstmateriale. Dei to feiltypane representerer begge avvik i vokalisme, der spesielt den eine tyder på påverknad frå bokmål som til dømes øke for auke, leke for leike, medan den andre også har innslag av munnleg påverknad som posetiv for positiv og virke for verke. Utgangspunktet er eit datasett om normavvik («rettskrivingsfeil») i studenttekstar, og vi nyttar generaliserte lineære modellar i analysen.

Nøkkelord: Nynorsk; skrivefeil; teljedata; vokalismefeil; bokmålspåverknad; statistisk metode

\begin{abstract}
Is it possible to estimate how many spelling mistakes a writer using the nynorsk language might make from his or her aptitude to write a few specific mistakes? A statistic analysis

In this text, we explore the following question: Is it possible to estimate how many spelling mistakes a writer using the nynorsk language might make from his or her aptitude to write a few specific mistakes? The analysis of our data set indicates that two particular mistake types together form a good indicator of the total amount of spelling mistakes in our material. The mistake types represent vowel divergences, where one of the mistakes in particular seems to be influenced by the majority language in Norway, bokmål: øke for auke, leke for leike. The other type seems also to be influenced by spoken language, like posetiv for positiv and virke for verke. The text material is a data set describing mistakes in student texts, and we use generalized linear models in our analysis.
\end{abstract}

Keywords: 'Nynorsk'; spelling mistakes; count data; 'bokmål' influence; statistical methods Responsible editor: Per Henning Uppstad

Received: December, 2019; Accepted: September, 2020: Published: December, 2020

^Korrespondanse: Terje Myklebust, e-post: terjemy@hvl.no

(C) 2020 Terje Myklebust og Jan Olav Fretland. This is an Open Access article distributed under the terms of the Creative Commons Attribution 4.0 International License (https://creativecommons.org/licenses/by-nc/4.0/), allowing third parties to copy and redistribute the material in any medium or format and to remix, transform, and build upon the material for any purpose, even commercially, provided the original work is properly cited and states its license.

Citation: T. Myklebust $\mathcal{E}$ F. O. Fretland. "Kan forekomsten av nokre spesielle feiltypar predikere den samla førekomsten av rettskrivings- og bøyingsavvik i nynorsktekstar? Ein statistisk analyse” Nordic fournal of Literacy Research, Vol. 6(4), 2020, pp. 1-17. http://dx.doi.org/10.23865/njlr.v6.2080 


\section{Innleiing}

I dag finst det fleire undersøkingar som har registrert og systematisert feiltypane for nynorskskrivarar (Bjørhusdal \& Juuhl, 2017; Eiksund, 2017; Fretland, 2015; Fretland, Kjartansdottir \& Balevik, 2017; Melby, 2005; Wiggen, 1992). Dei fleste er knytt til elevtekstar, men det er òg gjort undersøkingar av nettekstar og av studenttekstar. Undersøkingane kan tyde på at nynorskelevar gjer fleire rettskrivingsavvik enn islandske elevar (Fretland et al., 2017).

Undersøkingane er nokså eintydige: Nynorskskrivarar gjer, som bokmålsbrukarar, mykje feil med dobbeltkonsonant, med og/å og med samansette ord (koke bok, Vestlands hus). Spesifikt for nynorskskrivarar er

- bruk av leksem som ikkje samsvarar med nynorsknorma

- vokalismefeil, monoftong for diftong i alle ordklassar

- sterke verb som blir bøygde svakt og bøying av svake verb i presens og preteritum

- hankjønnssubstantiv på -ing får -er/-ene i fleirtal

- hokjønnsord vert behandla som hankjønn

- inkjekjønn får feil bøying i fleirtal

(Sjå ei meir omfattande oversikt i Bjørhusdal \& Kløve Juuhl, 2017, s. 104-110.)

Bjørhusdal og Juuhl (2017) behandlar 113 tekstar skrivne av 26 nynorskelevar på sjette årssteget, fordelte på seks skular, frå skuleåret 2012-13. Resultata her viser at det er 9,8 feil pr. hundre ord i nynorsktekstane, nær det doble av det Wiggen (1992) fann for bokmål. Det store talet avvik som fell saman med bokmålsnorma i nynorsktekstane, kan vere ein indikasjon på at påverknad frå bokmål er ein svært viktig grunn til avvik i nynorsken. Dette stemmer overeins med Støfring (2019), som registrerte og kategoriserte avvik i 7 hovudkategoriar med totalt 33 tilhøyrande underkategoriar. Empirien var nær 300 tekstar frå 7 . klassingar både på nynorsk og bokmål. Eitt av hovudfunna er at det i fem av kategoriane er vesentleg fleire feil hjå nynorskelevar enn bokmålselevar, og at $40 \%$ av feila i nynorsktekstane fell saman med bokmålsnorma. Dette stemmer også overeins med det føreliggjande materialet frå undersøkinga til Fretland (2015, s. 183-186). Bjørhusdal og Juuhl (2017) avsluttar sin artikkel med å seie: «Kanskje er tida inne for å sjå bokmålssamanfallande avvik i nynorsktekstar som ei utfordring til språkdidaktikarane, ikkje fyrst og fremst til normeringspolitikarane» (Bjørhusdal \& Juuhl, 2017, s. 117). Svar på denne siste utfordringa er det lite av i dei undersøkingane vi har registrert.

Innanfor det filologiske feltet har altså registrering og systematisering av feil vore grunnleggjande i mange undersøkingar. Det har vore utarbeidt ulike metodiske tilnærmingar til korleis ein kan minske slike avvik, som i hovudsak byggjer på ei prioritering av dei feila ein finn flest av, kanskje særleg målbore av den sentrale ordboksredaktøren Alf Hellevik (sjå t.d. Hellevik, 1971). I fagboka Rett og godt av Fretland og Søyland (2015) er det skissert 10 hugsereglar for rett nynorsk for røynde nynorskbrukarar, for så vidt bygde på kjende forskingsfunn. Men generelt er det rett å seie at det finst berre 
prøvande konklusjonar, om nokon i det heile, på korleis ein kan meisle ut ein nynorskdidaktikk for å minske feila. «Skulegrammatikkdebatten i Noreg har i svært stor grad dreia seg om kvifor ein (eventuelt) skal undervise i grammatikk, og langt mindre om didaktikkens kva og korleis", hevdar såleis Haugen (2019, s. 8).

For ordens skuld må det likevel nemnast at det finst andre metodar som ikkje tar utgangspunkt i feilkategoriar. I internasjonal litteratur finn vi til dømes den såkalla Spelling Pronunciation method (Hilte \& Reitsma, 2006; Ocal \& Ehri, 2017). Metoden er spesielt aktuell der det er svak samanheng mellom fonem og grafem, og er derfor særleg aktuell i språk som har store innslag av dette fenomenet som til dømes engelsk. Norsk er i denne samanheng i ein mellomposisjon (Hagtvet \& Lyster, 2003). Andre metodiske tilnærmingar er tilpassa elevar med skrivevanskar (Gjessing, 1977). Det er og utvikla retteprogram med ulike algoritmar i botnen, som programmet Spell Checker (Sharma \& Gupta, 2015). Kor vidt dei ulike metodane fungerer, er sjølvsagt eit anna spørsmål og eit forskingsfelt i seg sjølv (for ei oversikt sjå Graham \& Santangelo, 2014).

Mange metodiske tilnærmingar til rettskriving byggjer som sagt på undersøkingar der feila er grupperte i ulike kategoriar. Bak slike metodikkar ligg det, om enn kanskje ikkje uttalt, ein tanke om at avvika innanfor kvar av kategoriane kan relaterast til kvarandre i ein eller annan forstand. Faktum er at dersom det ikkje var slik, måtte kvart ord og kvar feil sjåast på individuelt, slik det vert gjort til dømes i Pronunciation Spelling-metoden. Kategoriseringar ville då ha liten funksjon for å utarbeide rettskrivingsmetodar og for å analysere og forstå kvifor skrivaren gjer dei feila han gjer. Jamvel som oversikt ville kategoriseringar då ha liten verdi frå ein rettskrivingsståstad. I vårt datasett og i mange andre undersøkingar (Bjørhusdal \& Juuhl, 2017; Wiggen, 1992) følgjer kategoriane blant anna delvis grammatiske kategoriar, og ulike kategoriar for feil i konsonantisme og vokalisme. Val av kategoriar varierer i desse undersøkingane, men dei synest å ha ei teoretisk grunngjeving enten det no er grammatikk, fonetikk, morfologi eller andre kriterium som ligg til grunn. Dette er til forskjell frå kategoriane til Finbak (2004, 2005), som er valde på grunnlag av empiri via faktoranalyse, og slik sett er dei ikkje teoretisk grunna. Finbak opererer med tre hovudkategoriar, to som har med fonetikk å gjere, og éin som dreiar seg om morfologi. Andre undersøkingar har andre kategoriar, til dømes opererer Gjessing (1977) med to hovudkategoriar, auditive stavefeil og visuelle stavefeil.

\section{Problemstilling}

Vi hevdar altså at i den grad formålet med feilregistreringar i kategoriar er å utvikle didaktiske metodar til hjelp i skriveopplæringa, så må tanken vere at ulike feil innanfor ein kategori er relaterte til kvarandre på ein eller annan måte som kan auke vår forståing for desse avvika og utnyttast i skriveopplæringa. I denne artikkelen tar vi denne tankegangen eit steg vidare. Vi ønskjer å finne ut om det er spesielle avvikstypar som kan avsløre eller seie noko om den samla førekomsten av avvik hjå nynorskskrivande. Med andre ord ser vi etter om det er nokre feilkategoriar som særleg indikerer at vi har å gjere med ein skrivar som gjer mange feil samla sett. 


\section{T. Myklebust \&o f. O. Fretland}

Vi kan ikkje finne at dette spørsmålet har vore undersøkt i forskingslitteraturen. Men som vi diskuterte ovanfor, er ikkje den grunnleggande ideen i problemstillinga, nemleg at ulike avvik avhenger av kvarandre, framand. Det er snarare grunnideen bak både systematiseringar for å analysere og forsøke å forstå rettskriving, og for metodiske tilnærmingar til rettskriving. Sjølve grunntanken om å sjå etter empiriske samanhengar mellom ord og ordval og i vårt tilfelle avvik, kjenner vi også frå forsking innan liknande fenomen som bruken av konservative/radikale former i nynorsk (Helset, 2016), og som nemnt er han nokon gonger utgangspunktet for val av kategoriar (Finbak, 2004, 2005). Magalhães et al. (2020) har undersøkt avvik hjå portugisiske barn og mellom anna sett på om avvika er ulike i ulike klassesteg. Samanlikningane er på kategorinivå, dei byggjer altså på ideen om at det er samanheng mellom avvik som fell i same kategori.

\section{Kvifor er problemstillinga interessant?}

I skriveopplæringa kan det i utgangspunktet synast riktig å legge særleg vekt på kategoriar med mange feil, men det er ikkje nødvendigvis den mest formålstenlege tilnærminga dersom det finst kategoriar med færre feil som i stor grad predikerer det totale talet på feil hjå skrivaren. Då må det undersøkast om slike kategoriar faktisk kan vere vel så viktige.

Dersom det finst slike enkeltavvik (kategoriar) som kan predikere den totale feilmengda, kan det kanskje vere ein kime til å forstå noko om kvifor skrivaren gjer dei feila ho/han gjer, altså å forsøke å forstå samanhengar mellom ulike feil utover den enkelte feilen. Dersom hyppige feil i éin kategori viser seg å auke den forventa totale feilmengda, kan det tyde på at feil i denne kategorien avslører ei manglande forståing som også påverkar mange andre feiltypar. Ein kan til dømes tenkje seg at mange feil i ein kategori avslører ei manglande grammatisk forståing som også påverkar andre kategoriar. Eller ein kan tenkje seg at feila skuldast spesielle fonetiske problem som er særleg synlege i visse kategoriar, men som i tillegg har generell innverknad. Primært må ein då jobbe mot ein forklaringsmodell for kvifor nett dei aktuelle avvikstypane er så sentrale, og kanskje bør nynorskdidaktikken rettast spesielt mot dei.

I tillegg til at denne typen kunnskap kan vere interessant frå eit læringsperspektiv, kan slik kunnskap også vere interessant $\mathrm{i}$ eit vurderingsperspektiv. I eit vurderingsperspektiv vil feil i kategoriar som typisk gir mange feil, generelt kunne vurderast som meir alvorlege enn feil i kategoriar som ikkje indikerer tilbøyelegheit til å gjere mange feil.

\section{Datasettet}

Datasettet består av talet på normavvik i studenttekstar på nynorsk skrivne av studentar ved Høgskulen i Sogn og Fjordane. Registreringsarbeidet er gjort av Jan Olav Fretland i 2007 og er utgangspunktet for fleire artiklar (Fretland, 2007, 2011, 2015; Myklebust \& Fretland, 2017). Feiltypane er delt inn i atten ulike kategoriar. Det 
er høvesvis 44, 43, 25 og 13 tekstar skrivne av studentar i makroøkonomi, mikroøkonomi, pedagogikk og førskulelærarutdanninga ved dåverande Høgskulen i Sogn og Fjordane. Det er éin tekst per person. Tekstane er skrivne på nynorsk. Sidan det ikkje er spesifikke krav om målform, går vi ut frå at nynorsk er hovudmålet til studentane. Registreringa er bygd på dei om lag fire første sidene med normal handskrift $\mathrm{i}$ kvar tekst. Vi kan altså gå ut frå at tekstane er omtrent like lange. Feilkategoriane er merkte som på førsteaksen i figur 1. Grovt sett står bokstaven A for allmenn ordlegging, $\mathrm{B}$ for bøyingsfeil, $\mathrm{C}$ for feil i vokalisme og konsonantisme og D for morfemfeil. Avvika er så delt inn i fleire underkategoriar: Kategori $\mathrm{A}$ er behandla i ein tidlegare artikkel (Fretland, 2011); derfor er det berre med A4, enkelt bestemt substantiv, i dette datasettet. B-kategoriane beskriv bøying av substantiv (B1) og bøying av verb (B2). C-kategoriane beskriv avvik i rettskriving, C3 med vokalar, C4 med konsonantar. D-gruppa beskriv morfemavvik, D1 påverknad frå bokmål, D2 feil med kjønn på substantiv. (For ei nærare forklaring sjå Fretland, 2015, s. 180-181.) Tabell 1 og figur 1 gir ei kort oversikt over storleiken til datasettet, det vil seie talet på feil og korleis feila fordeler seg på dei ulike kategoriane i dei ulike gruppene.

Tabell 1. Tabellen viser gjennomsnittleg tal feil per tekst i dei ulike gruppene

\begin{tabular}{cccc}
\hline \multicolumn{5}{c}{ Tal feil i gjennomsnitt per tekst $\mathbf{i}$ dei ulike gruppene } \\
\hline Mikro & Makro & Pedagogikk & Førskule \\
\hline 7,80 & 12,37 & 11,04 & 11,77 \\
\hline
\end{tabular}

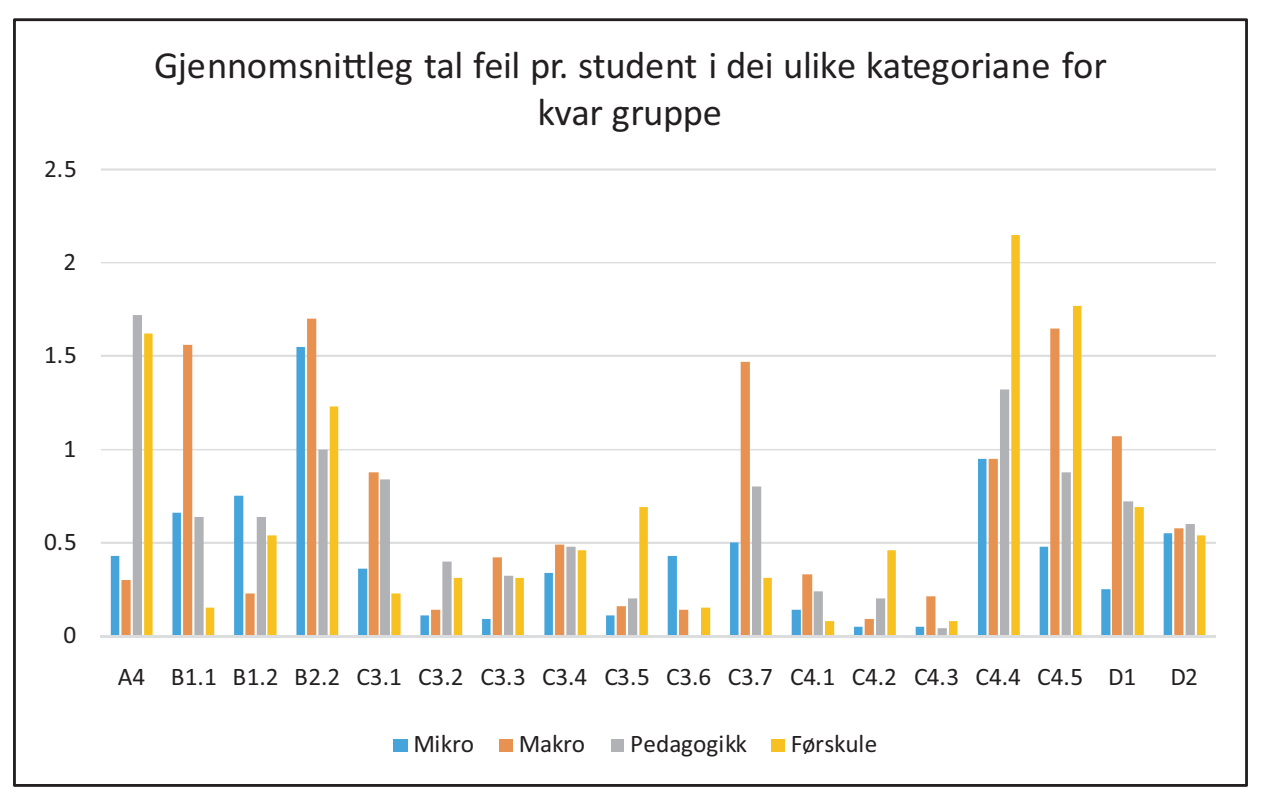

Figur 1. Stolpane viser gjennomsnittleg tal feil per tekst i dei ulike kategoriane for kvar av dei fire gruppene. 


\section{Metode}

Vi modellerer talet på førekomstar av dei ulike feiltypane med ei såkalla negativ binomialfordeling (Hilbe, 2011). Det vil seie at vi modellerer førekomstane av dei ulike feiltypane som ein prosess som er utsett for tilfeldigheiter, i den forstand at tal feil som ein tekstforfattar gjer i dei ulike kategoriane, vil variere frå tekst til tekst (sjå Myklebust \& Fretland, 2017). At det varierer, kan ha ulike grunnar, som til dømes dagsform, «slurvefeil» og ikkje minst at ulike tekstar har ulike ord. Men i tillegg til slike tilfeldige avvik kan det finnast systematiske avvik, og det er desse avvika vi er interesserte i. Problemet er at dei tilfeldige avvika gjerne skygger for dei systematiske avvika.

Vi vil studere i kor stor grad talet på feil i dei ulike kategoriane kan predikere den resterande totale feilmengda. Til det brukar vi såkalla generaliserte lineære modellar (Cameron \& Trivedi, 2013; Hilbe, 2011).

La $X_{k}$ vere talet på feil i kategori $k$. Til dømes er $X_{B 1.1}$ talet på feil i kategori B1.1. La $T$ vere summen av alle feila i ein tekst, vi kallar det den totale feilmengda, det vil seie at

$$
T=X_{A 4}+X_{B 1.1}+\cdots+X_{D 2}
$$

La

$$
T_{-k}=T-X_{k}
$$

det vil seie at $T_{-k}$ er den totale feilmengda bortsett frå feila i kategori $k$. Til dømes er $T_{-B 1.1}=T-X_{B 1.1}$, altså den totale feilmengda bortsett frå talet på feil i kategori B1.1.

Vi modellerer talet på feil i kvar av dei ulike kategoriane med ei negativ binomialfordeling, til dømes antar vi at $X_{B 1.1}$ er negativ binomialfordelt for ein tilfeldig observert tekst. Vi reknar også med at $T_{-k}$ er negativ binomial fordelt. Sjå Myklebust og Fretland (2017) for nærmare detaljar. Vi brukar ein såkalla generalisert lineær modell, der vi altså brukar negativ binomialfordeling, og vi vel identitetsfunksjonen som den såkalla linkfunksjonen. Valet er her grunna i at det gir ei enkel og forholdsvis kjent tolking som ligg nær opp til lineær regresjon. Det betyr at vi modellerer ein lineær samanheng mellom den forventa totale feilmengda og talet på feil i den aktuelle kategorien. Det vil seie at

$$
E\left(T_{-k}\right)=\beta_{\text {gruppe }}+\beta_{k} x_{k}
$$

der $E\left(T_{-k}\right)$ står for forventa tal feil av variabelen $T_{-k}$, og der kategorivariabelen gruppe tar verdiane Makro, Mikro, Pedagogikk eller Førskule.

Vi arbeider her utforskande, (Myklebust \& Fretland, 2017; Tukey, 1977, 1980). Dette gjeld spesielt siste del av artikkelen der vi ser etter fleire enn éin predikator. Grunnen er at vi ikkje stiller med klare hypotesar som vi ønskjer å testa. Så langt vi har kunna sjekke finst det verken teori eller empirisk forsking som seier noko om samanhengar mellom talet på feil i dei ulike kategoriane og den totale feilmengda. Derfor ønskjer vi å sjå om datasettet indikerer slike samanhengar. Det betyr at det beste vi kan oppnå her er å formulere moglege hypotesar, som då må testast på eit 
seinare tidspunkt. Det er elles verdt å merke seg at eventuelle samanhengar mellom ulike feiltypar sjeldan vil vere lett synlege. Derfor krevst det faktisk eit datasett og ein nærmare analyse sjølv berre for det å danne seg eit første innblikk på dette området.

Datasettet er ikkje optimalt, sidan vi berre observerer talet på feil i dei ulike kategoriane i staden for andelen av orda som er feil i kategoriane. Med andre ord har ulike tekstar ulikt potensial for feil i dei ulike kategoriane, men vi har dessverre ikkje noko informasjon om dette potensialet. Dette problemet er diskutert inngåande i Myklebust og Fretland (2017). Det er likevel grunn til å tru at desse problema er mindre når vi ser på samanhengar mellom feiltypane, slik vi gjer i denne artikkelen, enn dei er om vi skulle samanlikne sjansar for feil i ulike kategoriar. Det vil vi her kort argumentere for. Gå no ut frå at den forventa totale feilmengda utanom kategori $k$ aukar når talet på feil i kategori $k$ aukar. Det verkar ikkje plausibelt at mange feil i kategori $k$, som eventuelt har samanheng med mange ord i denne kategorien, skulle auke det forventa talet på ord i andre kategoriar og såleis auke sjansen for fleire feil i desse kategoriane. Det verkar meir rimeleg at samanhengen skuldast at personar med mange feil i kategori $k$ faktisk har større sjanse for å gjere feil generelt.

Eit ankepunkt mot å bruke denne typen modellar her, er at forklaringsvariabelen kanskje ikkje er optimal.Vi burde hatt tekstforfattarens forventningsverdi i kategorien som forklaringsvariabel, men vi har berre den observerte verdien. Argumentet for å ønske forventningsverdien er at det er rimeleg å tenkje seg at det er tekstforfattarens faktiske tilbøyelegheit til å gjere feil i ein bestemt kategori som eventuelt predikerer den totale feilmengda, og ikkje om forfattaren tilfeldigvis har giort få/mange feil i kategorien i denne teksten. Gitt at forventningsverdien er den ønskte forklaringsvariabelen, då er den observerte verdien berre eit estimat av forklaringsvariabelen, og estimatet er utsett for tilfeldige feil og derfor ikkje optimalt. På den andre sida vil ein i ein praktisk situasjon sjeldan ha tilgang på forventningsverdien (eller eit godt estimat av denne som er betre enn den observerte verdien), det vil oftast berre vere den observerte verdien i den aktuelle teksten som er tilgjengeleg.

\section{Om modelleringa og tolking av dispersjonsparameteren i modellen}

Vi vil grunngje korleis modelloppbygginga kan leie til val av negativ binomialfordeling. For ein gitt tekst modellerer vi talet på feil i kvar kategori med ei såkalla Poisson-fordeling. Vidare har kvar tekst si eiga Poisson-fordeling, det vil seie at det forventa talet på feil varierer frå tekst til tekst. Under visse føresetningar kan vi då modellere talet på feil i ein tilfeldig vald tekst med ei negativ binomialfordeling (Myklebust \& Fretland, 2017). Her inngår den såkalla dispersjonsparameteren som kan tolkast som eit mål på kor ulik feilsjanse dei ulike tekstane har, eller meir korrekt som eit mål for kor mykje det forventa talet på feil varierer mellom dei ulike tekstane. Vi føreset no at sjansen for feil i ein tekst blir avgjort av forfattaren og ikkje av teksten. Dersom alle tekstane var skrivne av same person, skulle då dispersjonsparameteren vere null under desse føresetnadane. Altså kunne talet på feil då modellerast med den same 


\section{T. Myklebust Eீ F. O. Fretland}

Poisson-fordelinga i alle tekstane. Med andre ord er ein liten dispersjonsparameter eit teikn på at det forventa talet på feil er nokså likt i alle tekstane, medan ein stor dispersjonsparameter er eit teikn på at forfattarane har svært ulike sjansar for å gjere feil. Det same er tilfelle om det forventa talet på feil var ulikt i dei ulike tekstane dersom forskjellen kunne forklarast med kjennskap til éin eller fleire prediksjonsvariablar. Motsett, om ein prediksjonsvariabel forklarar lite, skulle dispersjonsparameteren vere relativt upåverka av om ein inkluderer variabelen eller ikkje i modellen.

\section{Analyse}

I kva grad kan førekomstane av dei einskilde feiltypane predikere den totale feilmengda? Først studerer vi prediksjonsevna til éin variabel om gongen, deretter ser vi på prediksjonsevna når vi inkluderer fleire prediksjonsvariablar. Statistikkprogrammet SPSS er brukt i dataanalysen.

Tabell 2. Tabellen gjeld alle tekstane, og viser høvesvis, kategorinamn, predikatorvariabel, det maksimale talet på feil som er observert i ein tekst i den aktuelle kategorien, estimert koeffisient $\beta_{k}$, standardavviket til den estimerte $\beta_{k}$, nedre grense i $99 \%$-konfidensintervallet for $\beta_{k}$ når ho er større enn null, $\mathrm{p}$-verdien for null hypotesen at $\beta_{k}=0$ mot alternativet at $\beta_{k}>0$ og til slutt dispersjonsparameteren til residualane.

\begin{tabular}{|c|c|c|c|c|c|c|c|}
\hline \multirow[b]{2}{*}{$\begin{array}{l}\text { Kategori } \\
\boldsymbol{k}\end{array}$} & \multicolumn{7}{|c|}{ Alle tekstane $E\left(T_{-k}\right)=\boldsymbol{\beta}_{g r u p p e}+\boldsymbol{\beta}_{k} x_{k}$} \\
\hline & $\begin{array}{c}\text { Predikator } \\
\text { Variabel } \\
X_{k} \\
\end{array}$ & $\begin{array}{c}\text { Maks } \\
\text { feil per } \\
\text { tekst }\end{array}$ & $\begin{array}{c}\text { Estimert } \\
\beta_{k}\end{array}$ & $\begin{array}{c}\text { Stdav } \\
\left(\hat{\beta}_{k}\right)\end{array}$ & $\begin{array}{c}\text { Nedre grense, } \\
99 \% \text {-konfidens- } \\
\text { intervall } \\
\end{array}$ & p-verdi & $\begin{array}{c}\text { Dispersjons- } \\
\text { parameteren, } \\
\alpha \\
\end{array}$ \\
\hline $\mathrm{A} 4$ & $X_{A 4}$ & 8 & 0,01 & 0,45 & $<0$ & 0,981 & 0,213 \\
\hline $\mathrm{B} 1.1$ & $X_{B 1.1}$ & 8 & 1,55 & 0,41 & 0,51 & 0,000 & 0,134 \\
\hline $\mathrm{B} 1.2$ & $X_{B 1.2}$ & 4 & 0,84 & 0,61 & $<0$ & 0,170 & 0,187 \\
\hline B2.2 & $X_{B 2.2}$ & 6 & 0,62 & 0,34 & $<0$ & 0,072 & 0,205 \\
\hline $\mathrm{C} 3.1$ & $X_{C 3.1}$ & 6 & 2,24 & 0,57 & 0,76 & 0,000 & 0,130 \\
\hline $\mathrm{C} 3.2$ & $X_{C 3.2}$ & 2 & 1,50 & 1,22 & $<0$ & 0,222 & 0,188 \\
\hline $\mathrm{C} 3.3$ & $X_{C 3.3}$ & 2 & 3,42 & 1,15 & 0,44 & 0,003 & 0,159 \\
\hline $\mathrm{C} 3.4$ & $X_{C 3.4}$ & 2 & 1,19 & 0,85 & $<0$ & 0,161 & 0,194 \\
\hline C 3.5 & $X_{C 3.5}$ & 2 & 1,76 & 1,31 & $<0$ & 0,180 & 0,188 \\
\hline C3.6 & $X_{C 3.6}$ & 2 & 0,90 & 1,03 & $<0$ & 0,383 & 0,193 \\
\hline C3.7 & $X_{C 3.7}$ & 6 & 2,13 & 0,58 & 0,64 & 0,000 & 0,155 \\
\hline C4.1 & $X_{C 4.1}$ & 2 & 1,21 & 1,17 & $<0$ & 0,298 & 0,196 \\
\hline C4.2 & $X_{C 4.2}$ & 2 & 0,45 & 1,55 & $<0$ & 0,773 & 0,196 \\
\hline C4.3 & $X_{C 4.3}$ & 2 & 4,56 & 1,98 & $<0$ & 0,021 & 0,168 \\
\hline C4.4 & $X_{C 4.4}$ & 7 & 1,18 & 0,40 & 0,15 & 0,003 & 0,162 \\
\hline C4.5 & $X_{C 4.5}$ & 6 & 1,34 & 0,53 & $<0$ & 0,011 & 0,197 \\
\hline D1 & $X_{D 1}$ & 6 & 1,79 & 0,51 & 0,473 & 0,000 & 0,146 \\
\hline D2 & $X_{D 2}$ & 4 & 0,96 & 0,59 & $<0$ & 0,104 & 0,191 \\
\hline
\end{tabular}


I utgangspunktet viser høge koeffisientverdiar, $\beta_{k}$, sterk prediksjonsevne, men det er usikkerheit i dei estimerte koeffisientane. Vi vurderer usikkerheita i estimata ved standardavvika, konfidensintervalla og p-verdiane. Stort standardavvik indikerer usikkert estimat. Dersom p-verdien er høg og konfindensintervallet inneheld verdien null (nedre grense mindre enn null), er prediksjonsevna til variabelen usikker.

Variabelen $X_{A 4}$ (tal feil i A4) synest å vere uavhengig av den samla feilmengda ( $\beta_{A 4} \approx 0$ samt høg p-verdi). Variablane $X_{B 1.2}$ (tal feil i B1.2) og $X_{C 3.6}$ (tal feil i C3.6) synest heller ikkje å vere særleg gode predikatorar for den totale feilmengda. Elles er det generelle inntrykket at kvar og ein variabel i noka grad predikerer den totale feilmengde (utover variabelen sjølv). Målt ved storleiken til dei estimerte koeffisientane er tal feil i kategori C4.3 den mest betydningsfulle predikatoren $\left(\hat{\beta}_{C 4.3}=4,56\right)$, men standardavviket $(1,98)$ til estimatet er relativt høgt og p-verdien $(0,021)$ er også relativ høg samtidig som konfidensintervallet inneheld verdien null. Med andre ord er vår vurdering at estimatet av $\beta_{C 4.3}$ er relativt upåliteleg, og derfor tar vi ikkje med kategori C4.3 i den vidare analysen trass $\mathrm{i}$ at $\hat{\beta}_{C 4.3}=4,56$ er høgst av alle koeffisientestimata. Elles utmerkar variablane $X_{B 1.1}, X_{C 3.1}, X_{C 3.3}, X_{C 3.7}, X_{C 4.4}$ og $X_{D 1}$ seg som betydningsfulle predikatorar etter ei samla vurdering av høge koeffisientestimat som er støtta av $99 \%$-konfidensgrenser større enn null og låge p-verdiar.

Om vi korrigerer for multiple testar med Holm-Bonferronis metode (Chow \& Liu, 2008; Holm, 1979), får vi at variablane $X_{B 1.1}, X_{C 3.1}, X_{C 3.3}, X_{C 3.7}$ og $X_{D 1}$ har prediksjonsverdi på signifikansnivå $<1 \%$. Inkluderer vi også variabelen $X_{C 4.4}$, får vi p-verdi $<3 \%$.

Vi merkar oss at $\hat{\beta}_{C 3.3}=3,42$ er relativt høgt. Ingen har meir enn to feil i kategorien C3.3, men det er altså slik at sjølv så få som ein til to feil i denne kategorien er eit signal om at teksten har mange feil. Kan det vere ein indikasjon på at denne kategorien fangar opp noko generelt om ortografi-/bøyingsproblem, som er medverkande $i$ mange kategoriar og såleis påverkar den totale feilmengda?

\section{Er det tilsvarande samanhengar innanfor kvar gruppe?}

Vi sjekkar om det er konsistens mellom gruppene. Det er lite tillitvekkande dersom vi finn svært ulike samanhengar i dei ulike gruppene. Generelt kan det indikere at det er for oss ukjende forklaringsvariablar som er knytt til spesielle grupper som ligg bak. Til dømes kan det indikere at observerte samanhengar har å gjere med teksttypane heller enn med personane. Inkonsistens mellom gruppene aukar mistanken om at dei observerte resultata er tilfeldige og ikkje representerer ein generell tendens.

For mikrostudentane er koeffisientestimata gjennomgåande låge, og låge koeffisientar betyr liten prediksjonsverdi. Dessutan er det berre eitt signifikant utslag på 5 \%-nivå (kategori C4.4). Holm-Benferronis metode (Chow \& Liu, 2008) gir ein p-verdi på høge ca. $55 \%$ for at minst ein av koeffisientane i tabell 3 skal vere ulik null. Med andre ord finn vi ikkje signifikante samanhengar hjå mikrostudentane. Det synest med andre ord som om mikrostudentane berre gjer sporadiske feil. Samtidig gjer dei mindre feil enn dei andre gruppene (sjølv om det ikkje er veldige store forskjellar), jamfør tabell 1. Dei er med andre ord gode eller betre rettskrivarar enn 


\section{T. Myklebust Eீ F. O. Fretland}

Tabell 3. Tabellen gjeld mikrostudentane, og viser høvesvis, kategorinamn, predikatorvariabel, det maksimale talet på feil som er observert i ein tekst i den aktuelle kategorien, estimert koeffisient $\beta_{k}$, standardavviket til den estimerte $\beta_{k}$, p-verdien for nullhypotesen at $\beta_{k}=0$ mot alternativet at $\beta_{k}>0$ og til slutt dispersjonsparameteren til residualane.

\begin{tabular}{|c|c|c|c|c|c|c|}
\hline \multicolumn{7}{|c|}{ Berre mikrostudentane } \\
\hline $\begin{array}{l}\text { Kategori } \\
k\end{array}$ & $\begin{array}{c}\text { Predikator } \\
\text { Variabel }\end{array}$ & Maks feil & $\begin{array}{c}\text { Estimert } \\
\beta_{k}\end{array}$ & $\operatorname{Stdav}\left(\hat{\beta}_{k}\right)$ & p-verdi & $\begin{array}{c}\text { Dispersjons- } \\
\text { parameteren } \\
\alpha\end{array}$ \\
\hline A4 & $X_{A 4}$ & 2 & $-1,78$ & 0,84 & 0,983 & 0,081 \\
\hline $\mathrm{B} 1.1$ & $X_{B 1.1}$ & 3 & 0,72 & 0,55 & 0,097 & 0,038 \\
\hline B1.2 & $X_{B 1.2}$ & 4 & 0,48 & 0,56 & 0,198 & 0,055 \\
\hline $\mathrm{B} 2.2$ & $X_{B 2.2}$ & 5 & $-0,48$ & 0,37 & 0,903 & 0,127 \\
\hline C3.1 & $X_{C 3.1}$ & 4 & 0,62 & 0,64 & 0,165 & 0,039 \\
\hline C 3.2 & $X_{C 3.2}$ & 1 & 2,39 & 1,75 & 0,086 & 0,043 \\
\hline C3.3 & $X_{C 3.3}$ & 2 & 2,00 & 1,41 & 0,444 & 0,060 \\
\hline C3.4 & $X_{C 3.4}$ & 2 & 0,33 & 0,95 & 0,354 & 0,064 \\
\hline C3.5 & $X_{C 3.5}$ & 1 & $-1,67$ & 1,42 & 0,880 & 0,063 \\
\hline C3.6 & $X_{C 3.6}$ & 2 & 0,32 & 0,84 & 0,351 & 0,063 \\
\hline C3.7 & $X_{C 3.7}$ & 5 & 0,10 & 0,56 & 0,424 & 0,054 \\
\hline C4.1 & $X_{C 4.1}$ & 2 & 1,15 & 1,38 & 0,201 & 0,051 \\
\hline C4.2 & $X_{C 4.2}$ & 1 & $-0,79$ & 2,30 & 0,634 & 0,063 \\
\hline C4.3 & $X_{C 4.3}$ & 2 & 2,17 & 2,18 & 0,160 & 0,047 \\
\hline C4.4 & $X_{C 4.4}$ & 3 & 0,89 & 0,41 & 0,016 & 0,012 \\
\hline C4.5 & $X_{C 4.5}$ & 2 & 0,73 & 0,81 & 0,183 & 0,055 \\
\hline D1 & $X_{D 1}$ & 2 & $-0,27$ & 0,99 & 0,608 & 0,067 \\
\hline $\mathrm{D} 2$ & $X_{D 2}$ & 4 & 0,10 & 0,50 & 0,425 & 0,056 \\
\hline
\end{tabular}

dei andre studentane i materialet. Om ein ser desse to observasjonane saman, kan følgjande hypotese vere nærliggande: Sjølv ein forfattar som veit kva som er riktig og som i prinsippet derfor skulle kunne skrive ein feilfri tekst, kan gjere feil, men det er då typiske "slurvefeil» som førekjem på tilfeldige plassar i teksten. Derfor vil det heller ikkje vere samanhengar mellom ulike feiltypar hjå slike forfattarar. Hypotesen er med andre ord at ingen kategoriar predikerer den totale feilmengda blant gode rettskrivarar.

Ein annan interessant observasjon er at dei estimerte dispersjonsparametrane er relativt låge i mikrogruppa, og dei er mykje lægre enn når vi ser på heile datasettet. Det tyder på at denne gruppa er relativt homogen, som påpeika i Myklebust og Fretland (2017). Det er med andre ord vanskeleg å sjå forskjell på tekstane ut frå feilfordelingane. 
Tabell 4. Tabellen gjeld makrostudentane, og viser høvesvis, kategorinamn, predikatorvariabel, det maksimale talet på feil som er observert i ein tekst i den aktuelle kategorien, estimert koeffisient $\beta_{k}$, standardavviket til den estimerte $\beta_{k}$, p-verdien for nullhypotesen at $\beta_{k}=0$ mot alternativet at $\beta_{k}>0$ og til slutt dispersjonsparameteren til residualane.

\begin{tabular}{|c|c|c|c|c|c|c|}
\hline \multirow[b]{2}{*}{$\begin{array}{l}\text { Kategori } \\
k\end{array}$} & \multicolumn{6}{|c|}{ Berre makrostudentane } \\
\hline & $\begin{array}{c}\text { Predikator } \\
\text { Variabel }\end{array}$ & Maks feil & $\begin{array}{c}\text { Estimert } \\
\beta_{k}\end{array}$ & Stdav $\left(\hat{\beta}_{k}\right)$ & p-verdi & $\begin{array}{c}\text { Dispersjons- } \\
\text { parameteren } \\
\alpha\end{array}$ \\
\hline A4 & $X_{A 4}$ & 3 & $-0,92$ & 2,09 & 0,670 & 0,353 \\
\hline B1.1 & $X_{B 1.1}$ & 8 & 1,57 & 0,61 & 0,005 & 0,244 \\
\hline $\mathrm{B} 1.2$ & $X_{B 1.2}$ & 4 & 3,94 & 2,99 & 0,094 & 0,302 \\
\hline B 2.2 & $X_{B 2.2}$ & 6 & 2,04 & 0,71 & 0,002 & 0,271 \\
\hline $\mathrm{C} 3.1$ & $X_{C 3.1}$ & 6 & 3,47 & 1,03 & 0,001 & 0,196 \\
\hline $\mathrm{C} 3.2$ & $X_{C 3.2}$ & 1 & 4,19 & 4,22 & 0,161 & 0,327 \\
\hline C3.3 & $X_{C 3.3}$ & 2 & 5,07 & 2,17 & 0,010 & 0,268 \\
\hline C3.4 & $X_{C 3.4}$ & 2 & 2,76 & 1,95 & 0,079 & 0,329 \\
\hline C 3.5 & $X_{C 3.5}$ & 2 & 5,66 & 3,65 & 0,061 & 0,302 \\
\hline $\mathrm{C} 3.6$ & $X_{C 3.6}$ & 1 & 5,73 & 4,48 & 0,100 & 0,320 \\
\hline C 3.7 & $X_{C 3.7}$ & 6 & 2,88 & 0,90 & 0,001 & 0,252 \\
\hline C4.1 & $X_{C 4.1}$ & 2 & 2,23 & 2,38 & 0,175 & 0,343 \\
\hline C4.2 & $X_{C 4.2}$ & 1 & 4,10 & 5,18 & 0,214 & 0,332 \\
\hline C4.3 & $X_{C 4.3}$ & 2 & 6,91 & 3,36 & 0,020 & 0,267 \\
\hline C4.4 & $X_{C 4.4}$ & 5 & 3,44 & 1,17 & 0,002 & 0,234 \\
\hline C4.5 & $X_{C 4.5}$ & 6 & 1,47 & 1,05 & 0,081 & 0,402 \\
\hline D1 & $X_{D 1}$ & 6 & 2,97 & 0,85 & 0,000 & 0,185 \\
\hline D2 & $X_{D 2}$ & 4 & 3,46 & 1,61 & 0,016 & 0,290 \\
\hline
\end{tabular}

Pedagogikkgruppa og førskulegruppa er så vidt små at det vert nesten meiningslaust å sjå på dei kvar for seg. Vi vel derfor å studere dei som éi gruppe.

Vi repeterer at ein høg positiv koeffisient tyder at variabelen har høg prediksjonsverdi, og at låg p-verdi indikerer at koeffisienten faktisk er større enn null, sjølv om den estimerte verdien er usikker. Vi ser at talet på feil i kategoriane B1.1, B2.2, C3.1, C3.3 og C3.7, går att som gode predikatorar både hjå pedagogikk-førskulegruppa og hjå makrogruppa. Det er tillitvekkande. Derimot er variablane $X_{C 4.3}, X_{D 1}$ og $X_{D 2}$, som er sterke predikatorar i makrogruppa, ikkje signifikante predikatorar i pedagogikk-førskulegruppa. Og for $X_{C 4.5}$ er det omvendte tilfelle. Dette er ikkje tillitvekkande, og vi vel å ikkje gå vidare med desse kategorien her. Dei kan likevel vere verdt å ha under oppsyn i ei eventuell seinare gransking. Kategori C4.4 er også litt vekslande i makrogruppa og pedagogikk-førskulegruppa, men han er faktisk signifikant i mikrogruppa, og vi vel å ta han med i det vidare analysearbeidet. 


\section{T. Myklebust Eீ F. O. Fretland}

Tabell 5. Tabellen gjeld pedagogikk- og førskulestudentane samla, og viser høvesvis, kategorinamn, predikatorvariabel, det maksimale talet på feil som er observert i ein tekst i den aktuelle kategorien, estimert koeffisient $\beta_{k}$, standardavviket til den estimerte $\beta_{k}$, p-verdien for nullhypotesen at $\beta_{k}=0$ mot alternativet at $\beta_{k}>0$ og til slutt dispersjonsparameteren til residualane.

\begin{tabular}{|c|c|c|c|c|c|c|}
\hline \multirow[b]{2}{*}{$\begin{array}{l}\text { Kategori } \\
k\end{array}$} & \multicolumn{6}{|c|}{ Pedagogikk- og førskulestudentar } \\
\hline & $\begin{array}{c}\text { Predikator } \\
\text { Variabel }\end{array}$ & Maks feil & $\begin{array}{c}\text { Estimert } \\
\beta_{k}\end{array}$ & Stdav $\left(\hat{\beta}_{k}\right)$ & p-verdi & $\begin{array}{c}\text { Dispersjons- } \\
\text { parameteren } \\
\alpha \\
\end{array}$ \\
\hline $\mathrm{A} 4$ & $X_{A 4}$ & 8 & 0,44 & 0,46 & 0,172 & 0,114 \\
\hline B1.1 & $X_{B 1.1}$ & 2 & 3,06 & 1,31 & 0,010 & 0,080 \\
\hline $\mathrm{B} 1.2$ & $X_{B 1.2}$ & 2 & 0,11 & 1,12 & 0,466 & 0,135 \\
\hline B2.2 & $X_{B 2.2}$ & 4 & 1,11 & 0,65 & 0,042 & 0,093 \\
\hline $\mathrm{C} 3.1$ & $X_{C 3.1}$ & 6 & 0,91 & 0,89 & 0,155 & 0,104 \\
\hline $\mathrm{C} 3.2$ & $X_{C 3.2}$ & 2 & 0,13 & 1,31 & 0,460 & 0,133 \\
\hline $\mathrm{C} 3.3$ & $X_{C 3.3}$ & 2 & 2,95 & 1,63 & 0,036 & 0,094 \\
\hline C3.4 & $X_{C 3.4}$ & 2 & 0,51 & 1,38 & 0,357 & 0,133 \\
\hline C3.5 & $X_{C 3.5}$ & 2 & 1,03 & 1,61 & 0,262 & 0,123 \\
\hline C3.6 & $X_{C 3.6}$ & 1 & $-0,78$ & 3,61 & 0,586 & 0,127 \\
\hline C3.7 & $X_{C 3.7}$ & 2 & 2,23 & 1,32 & 0,045 & 0,108 \\
\hline C4.1 & $X_{C 4.1}$ & 1 & $-0,83$ & 2,15 & 0,650 & 0,141 \\
\hline C 4.2 & $X_{C 4.2}$ & 2 & $-0,09$ & 1,55 & 0,523 & 0,136 \\
\hline C4.3 & $X_{C 4.3}$ & 1 & $-2,89$ & 3,10 & 0,823 & 0,127 \\
\hline C4.4 & $X_{C 4.4}$ & 7 & 0,27 & 0,50 & 0,293 & 0,136 \\
\hline C4.5 & $X_{C 4.5}$ & 5 & 1,43 & 0,69 & 0,019 & 0,086 \\
\hline D1 & $X_{D 1}$ & 4 & 0,51 & 0,77 & 0,252 & 0,122 \\
\hline $\mathrm{D} 2$ & $X_{D 2}$ & 3 & 0,18 & 1,09 & 0,433 & 0,144 \\
\hline
\end{tabular}

Fleire predikatorar for den totale feilmengda: Ei utforskande tilnærming

Her utvidar vi og ser etter dei to til fire mest verknadsfulle variablane. Vi tar kategori A4 ut av datasettet i denne analysen. Kategori A4 synes å vere nokså uavhengig av den totale feilmengda, jamfør tabell 2, og opptrer derfor som støy i denne samanheng. La derfor $S$ vere summen av feila i alle kategoriane, bortsett frå feila i kategori A4, det vil seie at

$$
S=T-X_{A 4}
$$

For enkelheits skuld omtalar vi frå no av likevel $S$ som den totale feilmengda. Notasjonen for å utelate ein variabel frå summen $S$ er tilsvarande som for totalsummen $T$. Til dømes lar vi $S_{-C 3.3}=S-X_{C 3.3}$.Vi utvidar notasjonen på naturleg måte, slik at til dømes

$$
S_{-B 1.1,-B 2.2,-C 3.3}=S-X_{B 1.1}-X_{B 2.2}-X_{C 3.3}
$$

Noko av problemet med å ta med fleire predikatorvariablar er at for kvar ekstra variabel vi tar med, så vert den resterande feilmengda redusert. Det medfører blant anna at 
det kan vere vanskeleg å vurdere nytten av ein ekstra predikator sidan den resterande feilmengda endrar seg (minkar) for kvar ekstra predikator vi tar med.

Som diskutert i siste avsnitt i førre kapittel peikar $X_{B 1.1}, X_{B 2.2}, X_{C 3.1}, X_{C 3.3}, X_{C 3.7}$ og $X_{C 4.4}$ seg ut som dei beste predikatorane for den totale feilmengda. Vi ser derfor etter kva for to til fire av desse predikatorane som saman gir best prediksjon av den resterande totale feilmengda. Det fører likevel for langt å gjere greie for alle moglege kombinasjonar av to til fire av desse predikatorane, derfor presenterer vi berre hovudfunna.

Vi finn at variablane $X_{C 3.3}$ og $X_{C 3.7}$ ser ut til å vere dei to variablane som saman predikerer den resterande totale feilmengda best, og prediksjonen vert faktisk ikkje særleg betre av å inkludere fleire variablar.

Den estimerte forventninga til $S_{C 3.3-C 3.7}$ utan forklaringsvariablar,

$$
\hat{E}\left(S_{-C 3.3,-C 3.7}\right)=\hat{\beta}_{\text {gruppe },} \hat{\alpha}=0,212,
$$

$\operatorname{der} \hat{\beta}_{\text {gruppe }}$ er estimert til $\hat{\beta}_{\text {Mikro }}=6,3, \hat{\beta}_{\text {Makro }}=10, \hat{\beta}_{\text {Pedagogike }}=8,2$ og $\hat{\beta}_{\text {Forsulle }}=9,4$ for dei ulike gruppene. $\hat{\alpha}$ er dispersionsparameteren.

Når vi lar $X_{C 3.3}$ og $X_{C 3.7}$ vere forklaringsvariablar, får vi at

$$
\hat{E}\left(S_{-C 3.3,-C 3.7}\right)=\hat{\beta}_{\text {gruppe }}+3,01 x_{C 3.3}+1,76 x_{C 3.7}, \hat{\alpha}=0,128,
$$

$\operatorname{der} \hat{\beta}_{\text {gruppe }}$ då er estimert til $\hat{\beta}_{\text {Mikro }}=6,6, \hat{\beta}_{\text {Makro }}=5,7, \hat{\beta}_{\text {Pedagogike }}=5,8$ og $\hat{\beta}_{\text {Forskule }}=8,1$ for dei ulike gruppene.

Signifikansnivået er høvesvis 0,001 og 0,000 for dei to parametrane $\beta_{C 3.3}$ og $\beta_{C 3.7}$. Dette betyr til dømes at ein tekst som har 2 feil i kategori C3.3 og 6 feil i kategori C3.7 kan forventast å ha $3,01 \cdot 2+1,76 \cdot 6 \approx 17$ fleire feil i dei resterande kategoriane enn det ein tekst som ikkje har nokon feil i verken C3.3 eller C3.7 kan forventast å ha.

Når vi tar med predikatorane $X_{C 3.3}$ og $X_{C 3.7}$, er dispersjonsparameteren redusert frå 0,212 til 0,128 . Dette kan vere eit teikn på at desse to predikatorane forklarar mykje av det som ikkje skuldast rein slump. Under visse føresetnader vil, som tidlegare diskutert, ein dispersjonsparameter på null vere eit teikn på at desse to predikatorane forklarar heile den systematiske variasjonen mellom tekstane. Med andre ord kan dette tyde på at desse to prediktorane forklarar mykje av variasjonen som går ut over den heilt naturlege variasjonen som vi må forvente å finne, sjølv om dei ulike tekstane eigentleg berre var ulike delar av same tekst skriven av same person.

Når vi inkluderer dei to variablane $X_{C 3.3}$ og $X_{C 3.7}$ i modellen er det $X_{C 3.3}$ som er viktigast målt ved storleiken til koeffisienten, og vi făr omtrent same prediksjonsevne om vi byter ut $X_{C 3.7}$ med enten $X_{B 1.1}$ eller $X_{C 3.1}$. Det kan då tyde på at kategoriane C3.7, B1.1 og C3.1 representere omtrent like mykje nytt i forhold til C3.3 som ser ut til å representerer noko anna. Vi kan ikkje trekke dette for langt, men vi bør vurdere om det finst faglege forklaringar for at C3.3 saman med C3.7 eventuelt B1.1 eller C3.1 kan vere viktige predikatorar for skribentars tilbøyelegheit til å gjere rettskrivings- og bøyingsfeil i nynorsktekstar. 


\section{Dersom vi ikkje justerer for gruppene}

Vi har justert for gruppene i den forstand at gruppevariabelen er ein kategorisk variabel i modellen. Det er ikkje opplagt at det er riktig i denne situasjonen, men om vi ikkje justerer for gruppene vert resultatet omtrent det same. Dersom vi ikkje justerer for gruppene, får vi estimata $\hat{\beta}_{C 3.3}=3,10 \mathrm{og} \hat{\beta}_{C 3.7}=1,62$. I denne samanheng er det ein ubetydeleg forskjell frå dei tilsvarande estimata 3,01 og 1,76 som vi altså får når gruppevariabelen er med i modellen. Det er eit godt teikn at gruppene ikkje har stor innverknad.

\section{Diskusjon}

I denne artikkelen har vi studert i kva grad ulike førekomstar av dei ulike feiltypane kan forklare den totale feilmengda. Det kan sjå ut til at talet på førekomstar av feiltypane B1.1, C3.1, C3.3 og C3.7 er gode indikatorar for den totale feilmengda, i den forstand at mange feil her indikerer mange feil totalt sett. Det kan vidare sjå ut som at prediksjonsevna til desse variablane meir eller mindre er ivareteken av dei to variablane $X_{C 3.3}$ og $X_{C 3.7}$ (talet på feil i høvesvis C3.3 og C3.7). Kategoriane C3.3 og C3.7 er to av sju kategoriar av vokalismeavvik i materialet. C3.3 syner avvik i vokalparet i/e, som virke for verke, men og til dømes posetivt for positivt. C3.7 er døme der nynorsk har diftong og bokmål monoftong, som øke for auke, helt for heilt osv. Dei andre C3-kategoriane er også i hovudsak knytt til avvik på grunn av påverknad frå bokmål: e/a (uten-utan), o/a (holde-halde), æ/e (være-vere), å/o (åpen-open), u/o (budbod). Kategori B1.1 dekkjer feil fleirtalsbøying i hankjønn og hokjønn av substantiv (-er for -ar). Feila her må også klassifiserast som bokmålspåverknad.

Eit interessant poeng er at feil i kategori C3.3, avvik i vokalparet i/e, førekjem relativt sjeldan (Sjå figur 1 og kolonne 3 i tabell 2), men trass i det ser kategorien likevel ut til å vere ein viktig predikator for den totale feilmengda. Med andre ord kan sjølv sjeldan førekomande feiltypar vere interessante. Kan det tenkjast at C3.3 fangar opp noko som er særleg viktig for norskopplæring i skulen?

Det er eit norskfagleg/didaktisk og teoretisk spørsmål om dei observerte samanhengane kan ha meiningsfulle forklaringar. Spørsmålet er altså om det finst faglege argument for at mange feil i kategoriane C3.3 og C3.7 typisk gir mange feil generelt? Altså: fangar desse kategoriane på eitt eller anna vis opp ei manglande forståing som resulterer i mange feil generelt? I neste omgang og frå ein didaktisk synsvinkel er spørsmålet om ei eventuell forklaring kan utnyttast i skriveopplæringa.

Ei mogleg tilnærming til kvifor dei to kategoriane er relevante, kan vere følgjande: Både C3.3 og C3.7 er typiske døme på bokmålspåverknad i nynorsken (øke for auke, leke for leike, virke for verke). Det same gjeld som nemnt over i hovudsak alle C3kategoriane. C3.3 omfattar i tillegg munnleg påverknad i rettskrivinga (posetiv for positiv). Det er som nemnt i analysen, C3.3 og C3.7 som i størst grad ser ut til å utfylle kvarandre. Med andre ord ser dei ut til å representerer to ulike eigenskapar som kan vere viktige for feilintensiteten generelt. Er det slik at feil i C3.7 representerer at 
målformene vert blanda saman, men at skrivaren elles gjer det rett, medan C3.3, i alle fall delvis, representerer ein heilt annan feileigenskap som har å gjere med at ein skrivar ikkje skil mellom fonem og grafem? Samtidig må vi hugse at resultata våre tilseier at om det no er denne eller ei anna forklaring som er rett, så er det snakk om ei forklaring på eit generelt problem hjå skrivaren som ikkje berre gjeld C3.3-kategorien.

Elles verka det altså som at prediksjonsevna for den totale feilmengda ikkje aukar $\mathrm{i}$ særleg mon om vi inkluderte predikatorane B1.1 og C3.1, så lenge vi har med C3.7. B1.1 gjeld feil med hankjønn fleirtal (skatter for skattar), C3.1 gjeld andre som skriv -e for -a (uten for utan). Det tyder på at i den grad desse kategoriane, B1.1, C3.1 og C3.7, fangar opp eit generelt problem, så er det det same problemet det er snakk $\mathrm{om}$. Og vidare at om skrivaren har dette problemet, så vert det langt på veg avslørt av C3.7. Derimot ser det altså ut til at C3.3 i tillegg avslører eit anna problem. Det må seiast at ein skal vere forsiktig med å trekke desse slutningane for langt. Verken datasettet eller metoden vår gir grunnlag for å konkludere, likevel har vi fått eit hint om at desse spørsmåla kan vere verdt å undersøke nærmare.

Om vi går tilbake til bokmålspåverknad i C3.7 og for så vidt C3.1, så snakkar vi her primært om bokmålspåverka avvik i nynorsk vokalisme, særleg der nynorsk har diftong og bokmål monoftong (monoftongering). Fleire granskingar av skriveferdigheiter har peikt på problemet med bokmålsinnslag i nynorske elevtekstar (Matre et al., 2011; Skjelten, 2013). Bjørhusdal og Juuhl (2017, s. 114) peikar i si undersøking på at «Nynorskelevane i materialet vårt har bokmålssamanfallande avvik, særleg når det gjeld heile leksem, når det gjeld monoftongering, når det gjeld andre fonologiske/ ortografiske feil, og når det gjeld substantiv og verb i bøyingsverket». Dette samsvarar bra med funna vi legg fram ovanfor. Vi vil også peike på at i didaktiske tilnærmingar til nynorsk er det gjerne peikt på som ein viktig føresetnad for å skriva rett nynorsk, at studenten har eit medvite forhold til forskjellane mellom nynorsk og fleirtalsspråket bokmål, og til forskjellane mellom eigen dialekt og nynorsk. Vi kan her vise til didaktiske tilnærmingar, som i Fretland og Søyland (2015, s. 34-36), som mellom anna rår til ulike komparative tilnærmingar for å bevisstgjere elevar på forskjellane mellom nynorsk og dialekt og nynorsk og bokmål.

Dersom det verkeleg kan dokumenterast, gjennom nye og større datamengder, at talet på feil i kategoriane C3.3 og C3.7 er særs gode predikatorar for den samla mengda avvik, må det vere rett å spørje seg om det kan utnyttast i rettskrivingsdelen av nynorskundervisninga. Eit utgangspunkt kunne vere å utvikle eit sett med komparative teknikkar for å få redusert nett desse avvika. Om det vil kunne vere ein verknadsfull metodikk kan vanskeleg svarast på på førehand, men må derimot prøvast ut og evaluerast.

\section{Forfattarbiografi}

Terje Myklebust, førsteamanuensis, er dr. scient. i statistikk og har arbeidt i lærarutdanninga sidan 2000. Han er mellom anna medforfattar av ei lærebok i matematikk 
for lærarstudentar, og har publisert artiklar i statistikk i internasjonale tidsskrift på nivå $1 \operatorname{og} 2$.

Jan Olav Fretland, dosent norskdidaktikk. Var frå 1.2.2017 til 1.8.2018 programansvarleg for den nye grunnskulelærarutdanninga i HVL. Har arbeidt med skrivedidaktikk i skulen og med enklare språk i forvaltninga og har skrive mange fagbøker om temaet. Har siste åra arbeidt mest med masterutdanninga i læring og undervisning. Første rektor for Høgskulen i Sogn og Fjordane 1994-2000. Leiar i rådet for den nasjonale forskarskulen for lærarutdanning (NAFOL) til 2017.

\section{Referansar}

Bjørhusdal, E. \& Juuhl, G. K. (2017). Bokmålsavvik frå nynorsknorma i sjetteklassetekstar. Maal og Minne, 1, 93-121.

Cameron, A. C. \& Trivedi, P. K. (2013). Regression analysis of count data (2. utg.). New York: Cambridge university press.

Chow, S.-C. \& Liu, J.-P. (2008). Design and analysis of clinical trials: concepts and methodologies. Hoboken, New Jersey: John Wiley \& Sons.

Eiksund, H. (2017). Eitt språk - to kompetansar. Føresetnader for sidemål. I B. \&. Fondevik (Red.), Norsk som reiskaps- og danningsfag (258-283). Oslo: Samlaget.

Finbak, L. (2004). Stavefeil under lupen. Presentasjon av en pedagogisk modell for à beskrive stavefeil. Trondheim: Vox.

Finbak, L. (2005). Analyser av stavefeil. Spesialpedagogikk, 9, 20-29.

Fretland, J. O. (2007). Du skriv feil, lærar. I A. S. Norddal (Red.), Betre nynorskundervisning (s. 71-82). Volda: Nasjonalt senter for nynorsk i opplæringa. Høgskulen i Volda.

Fretland, J. O. (2011). Nynorsk ordval i studentoppgåver: Om «pengeetterspørselens inntektsfølsomheit» og andre nøtter for nynorsk i opplæringa. I T. E. Jenstad \& L. S. Vikør (Red.), Leksikalsk forsking $i$ norske målføre og nynorsk skriftspråk (161-176). Trondheim: Det Kongelige NorskeVidenskabers Selskabs Skrifter.

Fretland, J. O. (2015). "Vi analyserar økningen i isokvanter»: Ein analyse av nynorskfeil i studentarbeid. I H. Eiksund \& J. O. Fretland (Red.), Nye røyster i nynorskforskinga (s. 176-187). Oslo: Samlaget.

Fretland, J. O., Kjartansdottir, G. \& Balevik, I. (2017). Rettskriving i skriftkulturen-ulike perspektiv i Noreg og på Island. I J. R. Andersen, E. Bjørhusdal, J. G. Nesse \& Å. Torbjørn (Red.), Immateriell kapital. Fjordantologien 2017 (s. 131-145). Oslo: Universitetsforlaget.

Fretland, J. O. \& Søyland, A. (2015). Rett og godt - Handbok i nynorskundervisning. Oslo: Samlaget.

Gjessing, H.-J. (1977). Lese- og skrivevansker: dyslexi:problemorientering, analyse og diagnose, behandling og diagnose, behandling og undervisning. Oslo: Universitetsforlaget.

Graham, S. \& Santangelo, T. (2014). Does spelling instruction make students better spellers, readers, and writers? A meta-analytic review. Reading and Writing, 27(9), 1703-1743.

Hagtvet, B. E. \& Lyster, S.-A. H. (2003). The spelling errors of Norwegian good and poor decoders: A developmental cross-linguistic perspective. I N. K. Goulandris (Red.), Dyslexia in different languages: Crosslinguistic comparisons (s. 181-207). London: Whurr.

Haugen, T. A. (2019). Funksjonell grammatikk som metaspråk i skulen - ei moglegheit for djupnelæring i arbeid med språk og tekst. Acta Didactica Norge, 13(1), 9-22.

Hellevik, A. (1971). Norsk på ny. Oslo: Samlaget.

Helset, S. J. (2016). Tilhøvet mellom konservative, moderate og radikale former i nynorsk-ein studie av nynorskskrivaren sine språklege intuisjonar og val. Maal og Minne, 108(1).

Hilbe, J. M. (2011). Negative binomial regression. New York: Cambridge University Press.

Hilte, M. \& Reitsma, P. (2006). Spelling pronunciation and visual preview both facilitate learning to spell irregular words. Annals of Dyslexia, 56(2), 301-318.

Holm, S. (1979). A simple sequentially rejective multiple test procedure. Scandinavian journal of statistics, 6 , 65-70. 


\section{Kan førekomsten av nokre spesielle feiltypar predikere den samla førekomsten}

Magalhães, S., Mesquita, A., Filipe, M., Veloso, A., Castro, S. L. \& Limpo, T. (2020). Spelling Performance of Portuguese Children: Comparison Between Grade Level, Misspelling Type, and Assessment Task. Frontiers in Psychology, 11, 547.

Matre, S., Berge, K., Evensen, L., Fasting, R., Solheim, R. \& Thygesen, R. (2011). Developing National Standards for the Teaching and Assessment of Writing. Rapport frå forprosjekt Utdanning 2020. Trondheim: Nasjonalt senter for skriveopplæring og skriveforsking.

Melby, H. (2005). "No e e fardi me eksamen»: en undersøkelse av rettskrivingsavvik blant trønderske tiendeklassinger (Hovudoppgåve). Universitetet i Oslo, Oslo.

Myklebust, T. \& Fretland, J. O. (2017). Ein statistikkdiskusjon med utgangspunkt i normavvik i studenttekstar. I J. R. Andersen, E. Bjørhusdal, J. G. Nesse \& Å. Torbjørn (Red.), Immateriell kapital. Fjordantologien 2017 (s. 146-164). Oslo: Universitetsforlaget.

Ocal, T. \& Ehri, L. C. (2017). Spelling pronunciations help college students remember how to spell difficult words. Reading and Writing, 30(5), 947-967.

Sharma, S. \& Gupta, S. (2015). A correction model for real-word errors. Procedia Computer Science, 70, 99-106.

Skjelten, S. M. (2013). Fakta på kvalitetsforskjellar i elevane sine tekster. Kva skil gode tekstar frå middels gode? (Doktorgradsavhandling). Universitetet i Oslo, Oslo.

Støfring, A. S. (2019). Rettskriving $i$ nynorsk og bokmål: Ein studie av substantiv og verb $i$ tekstar skrivne av elevar på 7. trinn (Master oppgåve). Høgskulen på Vestlandet, Sogndal.

Tukey, J. W. (1977). Exploratory Data Analysis. Boston: Addison-Wesley.

Tukey, J. W. (1980). We need both exploratory and confirmatory. The American Statistician, 34(1), $23-25$.

Wiggen, G. (1992). Rettskrivings-studier II: kvalitativ og kvantitativ analyse av rettskrivingsavvik hos østnorske barneskoleelever (Doktorgradsavhandling). Oslo: Universitetet i Oslo. 